\title{
Article
}

\section{TSH Levels as an Independent Risk Factor for NAFLD and Liver Fibrosis in the General Population}

\author{
Alba Martínez-Escudé 1,2,*(D), Guillem Pera 1,3 ${ }^{(D}$, Anna Costa-Garrido 1,4 ${ }^{\text {Lluís Rodríguez }}{ }^{1,5}$, Ingrid Arteaga 1,6 \\ Carmen Expósito-Martínez 1,7, Pere Torán-Monserrat ${ }^{1,3}$ (D) and Llorenç Caballería 1,3 (D)
}

1 Unitat de Suport a la Recerca (USR) Metropolitana Nord, Fundació Institut Universitari d'Investigació en Atenció Primària Jordi Gol i Gurina (IDIAP Jordi Gol), Carrer de la Mare de Déu de Guadalupe 2, Planta 1'a 08303 Mataró, Spain; gpera@idiapigol.info (G.P.); annacostaga@gmail.com (A.C.-G.); lrodriguezg@gencat.cat (L.R.); iarteaga@gencat.cat (I.A.); cexposito.mn.ics@gencat.cat (C.E.-M.); ptoran.bnm.ics@gencat.cat (P.T.-M.); lcaballeria.bnm.ics@gencat.cat (L.C.)

2 Centre d'Atenció Primària La Llagosta, Institut Català de la Salut, 08120 La Llagosta, Spain

3 Centro de Investigación Biomédica en Red de Enfermedades Hepáticas y Digestivas (CIBEREHD), 28029 Madrid, Spain

4 Facultat de Matemàtiques, Universitat Autònoma de Barcelona, 08290 Cerdanyola del Vallès, Spain

5 Centre d'Atenció Primària Rocafonda-Palau, Institut Català de la Salut, 08303 Mataró, Spain

6 Centre d'Atenció Primària Santa Eulàlia, Institut Català de la Salut, 08187 Santa Eulàlia de Ronçana, Spain

7 Centre d'Atenció Primària Badia del Vallès, Institut Català de la Salut, 08214 Badia del Vallès, Spain

* Correspondence: amescude.mn.ics@gencat.cat; Tel.: +34-93-741-5338

check for

updates

Citation: Martínez-Escudé, A.; Pera, G.; Costa-Garrido, A.; Rodríguez, L.; Arteaga, I.; Expósito-Martínez, C.; Torán-Monserrat, P.; Caballería, L. TSH Levels as an Independent Risk Factor for NAFLD and Liver Fibrosis in the General Population. J. Clin. Med. 2021, 10, 2907. https://doi.org/ $10.3390 /$ jcm 10132907

Academic Editor: Gian Paolo Caviglia

Received: 9 June 2021

Accepted: 24 June 2021

Published: 29 June 2021

Publisher's Note: MDPI stays neutral with regard to jurisdictional claims in published maps and institutional affiliations.

Copyright: (C) 2021 by the authors. Licensee MDPI, Basel, Switzerland. This article is an open access article distributed under the terms and conditions of the Creative Commons Attribution (CC BY) license (https:/ / creativecommons.org/licenses/by/ $4.0 /)$.

\begin{abstract}
Thyroid hormones may be a risk factor for the development of non-alcoholic fatty liver disease (NAFLD) and its progression to liver fibrosis. The aim of this study is to investigate the relationship between thyroid stimulating hormone (TSH) levels, NAFLD, and liver fibrosis in the general population. A descriptive cross-sectional study was performed in subjects aged 18-75 years randomly selected from primary care centers between 2012 and 2016. Each subject underwent clinical evaluation, physical examination, blood tests and transient elastography. Descriptive and multivariate logistic regression analyses were used to identify factors associated with NAFLD and fibrosis. We included 2452 subjects ( $54 \pm 12$ years; $61 \%$ female). Subjects with TSH $\geq 2.5 \mu \mathrm{IU} / \mathrm{mL}$ were significantly associated with obesity, atherogenic dyslipidemia, metabolic syndrome (MetS), hypertransaminasemia and altered cholesterol and triglycerides. The prevalence of NAFLD and liver fibrosis was significantly higher in subjects with TSH $\geq 2.5(\mu \mathrm{IU} / \mathrm{mL})$. We found a 1.5 times increased risk of NAFLD, 1.8 and 2.3 times increased risk of liver fibrosis for cut-off points of $\geq 8.0 \mathrm{kPa}$ and $\geq 9.2 \mathrm{kPa}$, respectively, in subjects with $\mathrm{TSH} \geq 2.5 \mu \mathrm{IU} / \mathrm{mL}$ compared with $\mathrm{TSH}<2.5 \mu \mathrm{IU} / \mathrm{mL}$ (control group), independent of the presence of MetS. These findings remained significant when stratifying TSH, with values $\geq 10 \mu \mathrm{IU} / \mathrm{mL}$.
\end{abstract}

Keywords: thyroid stimulating hormone; thyroid function; metabolic syndrome; obesity; liver fibrosis; transient elastography; non-alcoholic fatty liver disease

\section{Introduction}

Non-alcoholic fatty liver disease (NAFLD) has become a major public health problem in recent decades, being the most common liver disease worldwide, with a prevalence between $25 \%$ and $30 \%$ of the adult population [1]. The main cause of the increase in its prevalence is the close relationship between NAFLD and different metabolic disorders, such as obesity, type 2 diabetes (T2DM), hypertriglyceridemia or metabolic syndrome (MetS), which in turn affect a large number of subjects today [2]. The heterogenicity in the distribution of the disease according to sub-populations with metabolic risk factors has led to a rethinking, even in the nomenclature of NAFLD, with the aim of identifying those patients with a higher risk of liver progression [3]. 
The main characteristic of NAFLD is fatty infiltration in more than $5 \%$ of hepatocytes, which is known as simple steatosis, in the absence of other chronic liver diseases (viral, alcoholic, drug, autoimmune) [4]. Later, this disease can progress to steatohepatitis, with different degrees of affectation, leading to the development of advanced liver fibrosis in $5-8 \%$ of patients $[5,6]$. Detecting liver fibrosis early is crucial as the severity of fibrosis predicts the development of liver cirrhosis and long-term survival.

Among the multiple extrahepatic complications that have been described in NAFLD, where metabolic and endocrinological disorders predominate, are alterations in thyroid function [7]. Thyroid hormones (TH) are involved in glycemic and lipid metabolism, as well as insulin resistance. The participation of TH in some physiopathological processes of NAFLD, such as the beta oxidation of free fatty acids, the cascade of pro-inflammatory cytokines, oxidative stress reactions or activation of stellate liver cells that lead to a fibrogenic response, make a possible relationship plausible [8]. Some studies have shown that hypothyroidism is more common in subjects with NAFLD [9]; others, that a low thyroid function is related to the risk of developing NAFLD, independently of other metabolic factors [10]. TH levels have also been associated with NAFLD [11] and liver fibrosis [12]. However, due to the heterogenicity of the populations studied and the different diagnostic criteria for defining the alteration of thyroid function and NAFLD or liver fibrosis, other authors have not found such a relationship [13,14]. Therefore, there is still some controversy regarding this association and more studies are required to clarify the role of $\mathrm{TH}$ in NAFLD.

For this reason, the main objective of this study is to analyze the relationship between the levels of thyroid stimulating hormone (TSH), NAFLD, and liver fibrosis in the general population.

\section{Methods}

\subsection{Study Design and Population}

For the design of this study, the cohort of a previous project was used, which was carried out between 2012 and 2016, and whose results were recently published [15]. A descriptive, cross-sectional, multi-center, population-based study was carried out, which included subjects aged 18 to 75 years, randomly selected from the Primary Care Information System (SIAP). All subjects were invited to participate in the study by telephone and underwent a clinical interview, a physical examination, a blood test, and a transient liver elastography, with prior informed consent.

To carry out this sub-study, 3060 participants from the reference cohort were selected. Individuals with known chronic liver disease, hepatotoxic drug use, severe advanced disease, cognitive impairment, institutionalization, and death were previously excluded. For this sub-study, only subjects with information on TSH levels were included. The specific exclusion criteria were: incomplete laboratory data $(n=202)$, absence or invalidity of liver elastography measurements $(n=46)$, inability to calculate the Fatty Liver Index (FLI) $(n=50)$ and weekly alcohol consumption of $\geq 21$ standard drink units (SDUs) in men and $\geq 14$ SDUs in women $(n=310)$. Finally, the sample obtained for data analysis was 2452 individuals.

\subsection{Clinical and Laboratory Parameters}

The variables that were collected were the following: age, sex, height, weight, waist circumference (WC), body mass index (BMI), systolic and diastolic blood pressure (SBP and DBP), tobacco and alcohol consumption in SDU. Individuals were also questioned for the presence of previous co-morbidities: arterial hypertension (HBP), hypercholesterolemia, hypertriglyceridemia and T2DM. These data were compared with the records in the computerized medical history. Blood tests were performed after a 12-h fast, including the determination of a complete blood count, TSH, alanine aminotransferase (ALT), aspartate aminotransferase (AST), gamma glutamyltransferase (GGT), alkaline phosphatase (ALP), ferritin, total proteins, albumin, glycemia, glycosylated hemoglobin, total choles- 
terol, high-density lipoprotein (HDL), low-density lipoprotein (LDL), and triglycerides (TG). Hypertransaminasemia was defined with ALT and/or AST values $>35 \mathrm{U} / \mathrm{L}$, using the cut-off point of our reference laboratory. Atherogenic dyslipidemia was established when TG levels $\geq 150 \mathrm{mg} / \mathrm{dL}$ and HDL levels $<40 / 50 \mathrm{mg} / \mathrm{dL}$ in men/women, respectively $[16,17]$. The normal range used for TSH values was $0.35-4.94 \mu \mathrm{IU} / \mathrm{mL}$ according to data from our reference laboratory.

\subsection{Evaluation of MetS}

The diagnosis of MetS was made according to the criteria established by the NCEPATPIII [18] when the subjects presented $\geq 3$ of the following components: WC $>88 \mathrm{~cm}$ women and $>102 \mathrm{~cm}$ men; TG $\geq 150 \mathrm{mg} / \mathrm{dL}$ or on lipid-lowering treatment; $\mathrm{HDL}<40 \mathrm{mg} / \mathrm{dL}$ in men and $<50 \mathrm{mg} / \mathrm{dL}$ in women or on lipid-lowering treatment; $\mathrm{BP} \geq 130 / 85 \mathrm{mmHg}$ or on hypotensive treatment; and baseline glycemia $\geq 100 \mathrm{mg} / \mathrm{dL}$ or on hypoglycemic treatment.

\subsection{Evaluation of NAFLD}

NAFLD was diagnosed using the FLI serological marker that includes the variables TG, BMI, GGT and WC; and is calculated from the following formula:

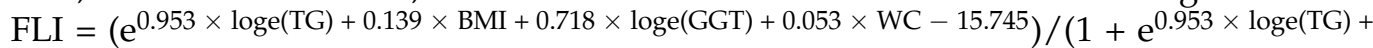
$0.139 \times \mathrm{BMI}+0.718 \times \log (\mathrm{GGT})+0.053 \times \mathrm{WC}-15.745) \times 100$. When the FLI score $\geq 60$ the diagnosis is NAFLD, FLI between 30 and 60 the diagnosis is indeterminate, and if FLI $<30$ no NAFLD [19].

\subsection{Evaluation of Liver Fibrosis}

Transient liver elastography (TE) was performed on each subject, using the $\mathrm{M}$ probe of the Fibroscan 402 apparatus (Echosens, Paris, France). Exclusion criteria were the inability to obtain 10 valid measurements and/or an interquartile range/liver stiffness (LS) measurement ratio greater than $30 \%$. Two cut-off points, suggestive of significant liver fibrosis, were defined according to LS values: $\geq 8.0$ kilopascals $(\mathrm{kPa})$ and $\geq 9.2 \mathrm{kPa}[15,20]$.

\subsection{Statistical Analysis}

For the descriptive analysis, the continuous variables were expressed as means and standard deviation, since they followed a normal distribution, and the categorical variables in frequencies and percentages. The prevalences were calculated with their respective $95 \%$ confidence intervals (95\% CI). In the bivariate comparisons of categorical variables, the Chi-square test was used, for the continuous variables in two groups the Student's $t$-test was used, and for comparisons in four groups analysis of variance was used.

The main outcome variables were, on the one hand, the presence of NAFLD (FLI $\geq 60$ ), and on the other, liver fibrosis, for which the LS measured by TE was used at two cut-off points $(\geq 8.0 \mathrm{kPa}$ and $\geq 9.2 \mathrm{kPa}$ ) used independently for the analyses. Subjects were stratified into various groups, according to TSH levels, to assess the risk of presenting NAFLD or liver fibrosis. The main TSH groups (model 1) for the study of the outcome variables were: TSH $<2.5 \mu \mathrm{IU} / \mathrm{mL}$, corresponding to the control group, and TSH $\geq 2.5 \mu \mathrm{IU} / \mathrm{mL}$, as an explanatory variable. Furthermore, in order to better define the subjects with $\mathrm{TSH} \geq 2.5 \mu \mathrm{IU} / \mathrm{mL}$, they were additionally sub-classified into three groups (model 2): TSH 2.50-4.94 $\mu \mathrm{IU} / \mathrm{mL}$, TSH 4.95-9.99 $\mu \mathrm{IU} / \mathrm{mL}$ and TSH $\geq 10 \mu \mathrm{IU} / \mathrm{mL}$. Multivariate logistic regression analyses were used in several models adjusted for potential confounding factors. The corresponding odds ratio (OR) and their $95 \% \mathrm{CI}$ were obtained. Statistical tests were performed with bilateral contrasts and statistical significance of $p<0.05$. The analyses were carried out with the R package version 4.0.2 (R development Core Team, GNU, GPL) and Rstudio version 1.2.5019 (R Foundation for Statistical Computing, Vienna, Austria). 


\section{Results}

\subsection{Basal Characteristics}

Of the 2452 subjects included in this study, $61 \%$ were female, $94 \%$ Caucasian, and they had a mean age of $54 \pm 12$ years. The prevalence of the different metabolic factors in the global sample were the following: T2DM $10 \%$, HBP $26 \%$, hypercholesterolemia $38 \%$, obesity $31 \%$, hypertriglyceridemia $11 \%$ and abdominal obesity $47 \%$. In addition, $27 \%$ of the subjects presented diagnostic criteria for MetS. Hypertransaminasemia affected $13 \%$ of the sample and NAFLD was found in 35\% of the cases.

The individuals were classified according to TSH levels into two groups (model 1): $66 \%$ with TSH $<2.5 \mu \mathrm{IU} / \mathrm{mL}(n=1619)$ and $44 \%$ with TSH $\geq 2.5 \mu \mathrm{IU} / \mathrm{mL}(n=833)$. Additionally, subjects with TSH $\geq 2.5 \mu \mathrm{IU} / \mathrm{mL}$ were stratified in (model 2): $86 \%$ with TSH $2.50-4.94 \mu \mathrm{IU} / \mathrm{mL}(n=718) ; 12 \%$ with TSH $4.95-9.99 \mu \mathrm{IU} / \mathrm{mL}(n=96)$ and $2 \%$ with $\mathrm{TSH} \geq 10 \mu \mathrm{IU} / \mathrm{mL}(n=19)$.

The baseline characteristics of the study subjects are shown in Table 1. Obesity, both global and abdominal, hypercholesterolemia, atherogenic dyslipidemia, MetS, and hypertransaminasemia were significantly more prevalent in the group with TSH $\geq 2.5 \mu \mathrm{IU} / \mathrm{mL}$ compared to the control group. Likewise, in these subjects higher levels of BMI, WC, total cholesterol, TG, ALT, AST, and ALP were observed. Similar findings were observed in the stratification of the subjects with TSH $\geq 2.5 \mu \mathrm{IU} / \mathrm{mL}$ in model 2. Furthermore, in the group with TSH $\geq 10 \mu \mathrm{IU} / \mathrm{mL}$, a higher prevalence of T2DM was found compared to the control group $(16 \%$ vs. $9.8 \%)$ and higher LDL levels $(p<0.001)$. However, although the prevalence of MetS in subjects with TSH $\geq 10 \mu \mathrm{IU} / \mathrm{mL}$ was higher ( $32 \%$ vs. $25 \%$ ), it was not significant.

Table 1. Basal characteristics of the subjects according to TSH levels ( $\mu \mathrm{IU} / \mathrm{mL})$.

\begin{tabular}{|c|c|c|c|c|c|c|c|}
\hline & \multirow[b]{2}{*}{$\begin{array}{l}\text { TSH }<2.5 \\
(n=1619)\end{array}$} & \multirow[b]{2}{*}{$\begin{array}{c}\text { TSH } \geq 2.5 \\
(n=833)\end{array}$} & \multirow[b]{2}{*}{$p$-Value } & \multicolumn{3}{|c|}{$\mathrm{TSH} \geq 2.5$} & \multirow[b]{2}{*}{$p$-Value * } \\
\hline & & & & $\begin{array}{c}\text { TSH } \\
2.50-4.94 \\
(n=718)\end{array}$ & $\begin{array}{c}\text { TSH } \\
4.95-9.99 \\
(n=96)\end{array}$ & $\begin{array}{c}\text { TSH } \geq 10 \\
(n=19)\end{array}$ & \\
\hline Age (years) & $54 \pm 12$ & $55 \pm 12$ & 0.013 & $55 \pm 12$ & $56 \pm 11$ & $52 \pm 9$ & 0.042 \\
\hline Female & $909(56 \%)$ & $592(71 \%)$ & $<0.001$ & $503(70 \%)$ & $76(79 \%)$ & $13(68 \%)$ & $<0.001$ \\
\hline \multicolumn{8}{|l|}{ Disease history } \\
\hline $\mathrm{T} 2 \mathrm{DM}$ & $158(9.8 \%)$ & $95(11 \%)$ & 0.205 & $88(12 \%)$ & $4(4.2 \%)$ & $3(16 \%)$ & 0.046 \\
\hline HBP & $421(26 \%)$ & $221(27 \%)$ & 0.779 & $201(28 \%)$ & $15(16 \%)$ & $5(26 \%)$ & 0.079 \\
\hline Hypercholesterolemia & $599(37 \%)$ & $344(41 \%)$ & 0.038 & $299(42 \%)$ & $36(38 \%)$ & $9(47 \%)$ & 0.157 \\
\hline Hypertriglyceridemia & $163(10 \%)$ & $101(12 \%)$ & 0.120 & $88(12 \%)$ & $12(13 \%)$ & $1(5.3 \%)$ & 0.337 \\
\hline Atherogenic dyslipidemia & $139(9.0 \%)$ & $107(13 \%)$ & 0.001 & $90(13 \%)$ & $14(15 \%)$ & $3(16 \%)$ & 0.009 \\
\hline Global obesity (BMI $\geq 30$ ) & $454(28 \%)$ & $294(35 \%)$ & $<0.001$ & $250(35 \%)$ & $34(35 \%)$ & $10(53 \%)$ & 0.007 \\
\hline Abdominal obesity & $705(44 \%)$ & $436(52 \%)$ & $<0.001$ & $370(52 \%)$ & $53(55 \%)$ & $13(68 \%)$ & $<0.001$ \\
\hline MetS & $405(25 \%)$ & $249(30 \%)$ & 0.010 & $216(30 \%)$ & $27(28 \%)$ & $6(32 \%)$ & 0.076 \\
\hline \multicolumn{8}{|l|}{ Physical examination } \\
\hline BMI & $28 \pm 5$ & $29 \pm 5$ & $<0.001$ & $29 \pm 5$ & $29 \pm 5$ & $30 \pm 6$ & 0.001 \\
\hline WC-Male (cm) & $98 \pm 11$ & $100 \pm 12$ & 0.032 & $100 \pm 12$ & $100 \pm 13$ & $101 \pm 8$ & 0.201 \\
\hline WC-Female $(\mathrm{cm})$ & $90 \pm 12$ & $92 \pm 13$ & 0.001 & $91 \pm 13$ & $93 \pm 12$ & $96 \pm 15$ & 0.003 \\
\hline $\mathrm{SBP}(\mathrm{mmHg})$ & $125 \pm 17$ & $125 \pm 17$ & 0.801 & $125 \pm 17$ & $126 \pm 16$ & $126 \pm 19$ & 0.903 \\
\hline $\mathrm{DBP}(\mathrm{mmHg})$ & $80 \pm 10$ & $81 \pm 10$ & 0.013 & $81 \pm 10$ & $81 \pm 11$ & $83 \pm 13$ & 0.066 \\
\hline \multicolumn{8}{|l|}{ Blood analysis } \\
\hline Platelets $\left(10^{9} / \mathrm{L}\right)$ & $244 \pm 59$ & $246 \pm 60$ & 0.471 & $245 \pm 61$ & $253 \pm 60$ & $251 \pm 47$ & 0.527 \\
\hline $\operatorname{ALT}(\mathrm{U} / \mathrm{L})$ & $23 \pm 13$ & $24 \pm 16$ & 0.047 & $24 \pm 16$ & $22 \pm 14$ & $29 \pm 19$ & 0.040 \\
\hline AST (U/L) & $23 \pm 8$ & $24 \pm 10$ & 0.025 & $24 \pm 10$ & $23 \pm 8$ & $25 \pm 8$ & 0.058 \\
\hline $\mathrm{ALT}$ and /or AST > $35(\mathrm{U} / \mathrm{L})$ & $189(12 \%)$ & $122(15 \%)$ & 0.036 & $107(15 \%)$ & $10(10 \%)$ & $5(26 \%)$ & 0.040 \\
\hline
\end{tabular}


Table 1. Cont.

\begin{tabular}{|c|c|c|c|c|c|c|c|}
\hline & \multirow[b]{2}{*}{$\begin{array}{l}\text { TSH }<2.5 \\
(n=1619)\end{array}$} & \multirow[b]{2}{*}{$\begin{array}{c}\text { TSH } \geq 2.5 \\
(n=833)\end{array}$} & \multirow[b]{2}{*}{$p$-Value } & \multicolumn{3}{|c|}{$\mathrm{TSH} \geq 2.5$} & \multirow[b]{2}{*}{$p$-Value * } \\
\hline & & & & $\begin{array}{c}\text { TSH } \\
2.50-4.94 \\
(n=718)\end{array}$ & $\begin{array}{c}\text { TSH } \\
4.95-9.99 \\
(n=96)\end{array}$ & $\begin{array}{c}\text { TSH } \geq 10 \\
(n=19)\end{array}$ & \\
\hline GGT (U/L) & $30 \pm 26$ & $31 \pm 32$ & 0.172 & $32 \pm 32$ & $27 \pm 25$ & $36 \pm 40$ & 0.233 \\
\hline ALP (U/L) & $77 \pm 24$ & $79 \pm 25$ & 0.019 & $79 \pm 25$ & $83 \pm 24$ & $89 \pm 15$ & 0.008 \\
\hline Ferritin (ng/mL) & $115 \pm 114$ & $105 \pm 110$ & 0.045 & $106 \pm 110$ & $104 \pm 114$ & $82 \pm 63$ & 0.181 \\
\hline Glycemia (mg/dL) & $100 \pm 24$ & $101 \pm 28$ & 0.181 & $101 \pm 28$ & $100 \pm 32$ & $96 \pm 21$ & 0.418 \\
\hline $\operatorname{HbA1c}(\%)$ & $5.7 \pm 0.7$ & $5.7 \pm 0.7$ & 0.199 & $5.7 \pm 0.7$ & $5.7 \pm 0.8$ & $5.6 \pm 0.3$ & 0.479 \\
\hline Total cholesterol (mg/dL) & $210 \pm 39$ & $216 \pm 38$ & $<0.001$ & $214 \pm 39$ & $225 \pm 35$ & $243 \pm 37$ & $<0.001$ \\
\hline HDL (mg/dL) & $55 \pm 13$ & $56 \pm 13$ & 0.018 & $56 \pm 13$ & $56 \pm 12$ & $53 \pm 7$ & 0.069 \\
\hline LDL (mg/dL) & $133 \pm 34$ & $135 \pm 34$ & 0.176 & $133 \pm 33$ & $144 \pm 32$ & $161 \pm 39$ & $<0.001$ \\
\hline $\mathrm{TG}(\mathrm{mg} / \mathrm{dL})$ & $115 \pm 68$ & $130 \pm 78$ & $<0.001$ & $129 \pm 77$ & $133 \pm 82$ & $154 \pm 58$ & $<0.001$ \\
\hline
\end{tabular}

* $p$ comparing four groups of TSH: $<2.5,2.50-4.94,4.95-9.99$ and $\geq 10 \mu \mathrm{IU} / \mathrm{mL}$. Note: The data are expressed in frequency (\%) or mean (SD). MetS diagnosed by NCEP-ATPIII criteria. Abbreviations: TSH, thyroid stimulating hormone; T2DM, type 2-diabetes mellitus; HBP, high blood pressure; MetS, metabolic syndrome; BMI, body mass index; WC, waist circumference; SBP, systolic blood pressure; DBP, diastolic blood pressure; ALT, alanine aminotransferase; AST, aspartate aminotransferase; GGT, g-glutamyltransferase; ALP, alkaline phosphatase; HbA1c, glycosylated hemoglobin; HDL, high density lipoprotein; LDL, low-density lipoprotein; TG, triglycerides.

\subsection{Relationship between TSH and NAFLD}

First, the relationship of TSH levels according to the presence of NAFLD was studied (Table 2). TSH levels were significantly higher in subjects with FLI $\geq 60$ (2.9 vs. $2.3 \mu \mathrm{IU} / \mathrm{mL}$ ). The prevalence of subjects with TSH $\geq 2.5 \mu \mathrm{IU} / \mathrm{mL}$ was higher in the presence of NAFLD compared to the group without NAFLD (39\% vs. $31 \% ; p<0.001)$. The prevalence of TSH alteration, in the stratified groups of model 2, was also higher in the group with NAFLD $(p<0.001)$.

Table 2. TSH levels and prevalence of TSH alteration according to presence of NAFLD.

\begin{tabular}{cccc}
\hline & $\begin{array}{c}\text { FLI }<\mathbf{6 0} \\
(\boldsymbol{n}=\mathbf{1 5 8 9})\end{array}$ & $\begin{array}{c}\text { FLI } \geq \mathbf{6 0} \\
(\boldsymbol{n}=\mathbf{8 6 3})\end{array}$ & $\boldsymbol{p}$-Value \\
\hline TSH level $(\mu \mathrm{IU} / \mathrm{mL})$ & $2.3 \pm 2.4$ & $2.9 \pm 6.2$ & $<0.001$ \\
Groups TSH $(n, \%)$ & $1089(69 \%)$ & $530(61 \%)$ & $<0.001$ \\
TSH $<2.5(\mu \mathrm{IU} / \mathrm{mL})$ & $500(31 \%)$ & $333(39 \%)$ & $<0.001 *$ \\
TSH $\geq 2.5(\mu \mathrm{IU} / \mathrm{mL})$ & $434(27 \%)$ & $284(33 \%)$ & \\
\hline TSH $2.50-4.94(\mu \mathrm{IU} / \mathrm{mL})$ & $61(3.8 \%)$ & $35(4.1 \%)$ & \\
TSH $4.95-9.99(\mu \mathrm{IU} / \mathrm{mL})$ & $5(0.3 \%)$ & $14(1.6 \%)$ & \\
TSH $\geq 10(\mu \mathrm{IU} / \mathrm{mL})$ & & & \\
\hline
\end{tabular}

* $p$ trend, comparing four groups of TSH: $<2.5,2.50-4.94,4.95-9.99, \geq 10 \mu \mathrm{IU} / \mathrm{mL}$. Abbreviations: FLI, fatty liver index; TSH, thyroid stimulating hormone.

Furthermore, the prevalence of NAFLD was analyzed according to TSH levels (Figure 1). NAFLD affected $40 \%$ of the subjects with TSH $\geq 2.5 \mu \mathrm{IU} / \mathrm{mL}(p=0.001)$. Moreover, NAFLD occurred more frequently when TSH levels were higher $(73.7 \%$ in subjects with $\mathrm{TSH} \geq 10 \mu \mathrm{IU} / \mathrm{mL})$. 


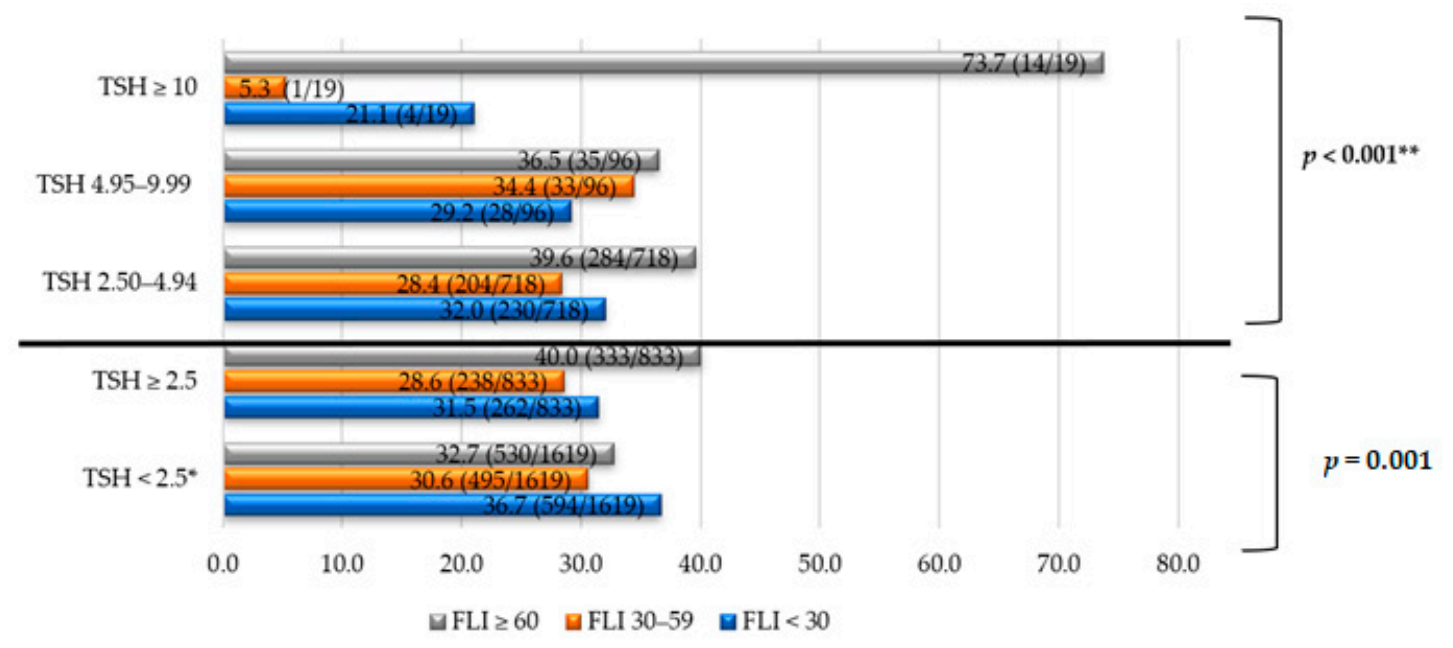

Figure 1. NAFLD prevalence according to TSH levels in different groups. Note: The data are expressed in \%. ${ }^{*}$ Comparison/control group. ${ }^{* *} p$ trend, comparing four groups of TSH: $<2.5,2.50-4.94,4.95-9.99, \geq 10 \mu \mathrm{IU} / \mathrm{mL}$. TSH units: $\mu \mathrm{IU} / \mathrm{mL}$. Abbreviations: NAFLD, non-alcoholic fatty liver disease; TSH, thyroid stimulating hormone; FLI, fatty liver index.

In multivariate analyses, the risk of presenting NAFLD according to TSH levels $\geq 2.5 \mu \mathrm{IU} / \mathrm{mL}$, compared to the control group, was 1.5 times greater regardless of age, sex, alcohol consumption, obesity, cholesterol, or MetS; and 1.33 times greater, regardless of the MetS parameters (Figure 2a).

(a)

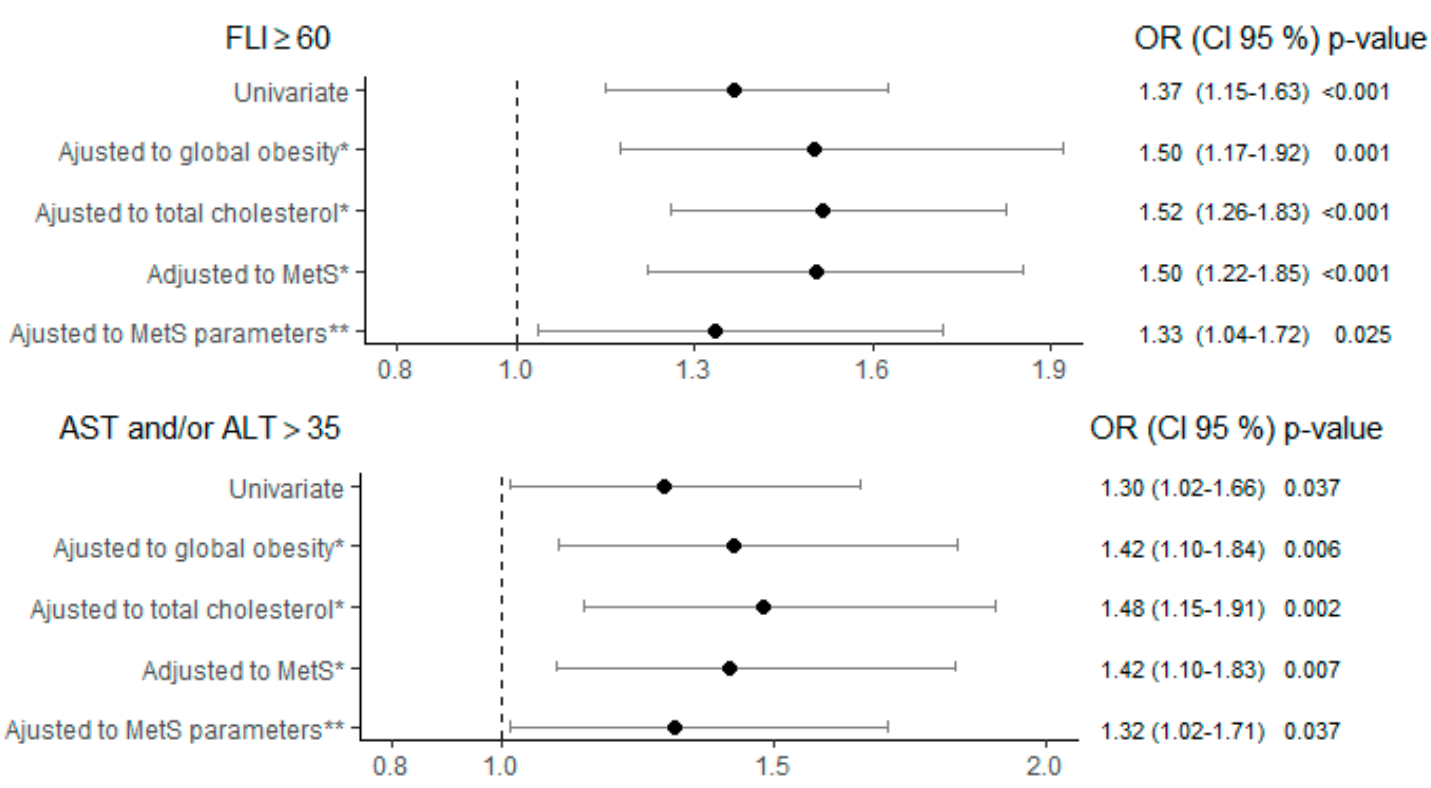

Figure 2. Risk of NAFLD (a) and hypertransaminasemia (b) according to TSH $\geq 2.5(\mu \mathrm{IU} / \mathrm{mL})$ adjusted to different metabolic factors. Note: Control reference group for the analysis $\mathrm{TSH}<2.5(\mu \mathrm{IU} / \mathrm{mL}) .{ }^{*}$ All multivariate analyses were adjusted also for age, sex and alcohol consumption. ${ }^{* *}$ MetS parameters: WC > 88W/102M cm; TG $\geq 150 \mathrm{mg} / \mathrm{dL}$; HDL $<50 \mathrm{~W} / 40 \mathrm{M} \mathrm{mg} / \mathrm{dL} ; \mathrm{BP} \geq 130 / 85 \mathrm{mmHg}$; Glyc $\geq 100 \mathrm{mg} / \mathrm{dL}$. Abbreviations: FLI, fatty liver index; MetS, metabolic syndrome; AST, aspartate aminotransferase; ALT, alanine aminotransferase; TSH, thyroid stimulating hormone; NAFLD, non-alcoholic fatty liver disease; WC, waist circumference; TG, triglycerides; HDL, high-density lipoprotein; BP, blood pressure; Glyc, glycemia.

To better explain these findings, the risk of NAFLD was analyzed in the different stratified TSH groups of model 2. Both the subjects with TSH $2.50-4.94 \mu \mathrm{IU} / \mathrm{mL}$ and those 
with TSH $\geq 10 \mu \mathrm{IU} / \mathrm{mL}$ showed a significant increase in the risk of NAFLD of 1.31 and 8.22 times, respectively, in relation to the control group, independently of age, sex, alcohol consumption, and the different parameters of MetS (Table 3). In addition, an excess risk of FLI $\geq 60$ with OR $>1$ was also obtained in these two TSH groups, in the other multivariate analyses carried out in separate models and adjusted for global obesity, total cholesterol, and presence of MetS. Although the ORs for the TSH 4.95-9.99 $\mu \mathrm{IU} / \mathrm{mL}$ group were $>1$, they did not reach statistical significance.

Table 3. Analysis of NAFLD risk according to TSH group. Four different multivariate logistic regression models, adjusting for obesity, cholesterol, MetS and MetS parameters.

\begin{tabular}{|c|c|}
\hline & FLI $\geq 60$ \\
\hline & OR (CI 95\%) $p$-value \\
\hline \multicolumn{2}{|l|}{ Univariate } \\
\hline TSH 2.50-4.94 ( $\mu \mathrm{IU} / \mathrm{mL})$ & $1.34(1.12-1.61) 0.001$ \\
\hline TSH 4.95-9.99 ( $\mu \mathrm{IU} / \mathrm{mL})$ & $1.18(0.77-1.81) 0.451$ \\
\hline $\mathrm{TSH} \geq 10(\mu \mathrm{IU} / \mathrm{mL})$ & $5.75(2.06-16.06)<0.001$ \\
\hline \multicolumn{2}{|l|}{ Multivariate ${ }^{*}$} \\
\hline \multicolumn{2}{|l|}{ Adjusted to global obesity } \\
\hline TSH 2.50-4.94 $(\mu \mathrm{IU} / \mathrm{mL})$ & $1.46(1.13-1.89) 0.004$ \\
\hline TSH 4.95-9.99 ( $\mu \mathrm{IU} / \mathrm{mL})$ & $1.28(0.71-2.31) 0.410$ \\
\hline $\mathrm{TSH} \geq 10(\mu \mathrm{IU} / \mathrm{mL})$ & $8.71(2.51-30.25)<0.001$ \\
\hline \multicolumn{2}{|l|}{ Adjusted to total cholesterol } \\
\hline TSH 2.50-4.94 $(\mu \mathrm{IU} / \mathrm{mL})$ & $1.49(1.23-1.81)<0.001$ \\
\hline TSH 4.95-9.99 $(\mu \mathrm{IU} / \mathrm{mL})$ & $1.29(0.83-2.02) 0.262$ \\
\hline $\mathrm{TSH} \geq 10(\mu \mathrm{IU} / \mathrm{mL})$ & $6.75(2.38-19.13)<0.001$ \\
\hline \multicolumn{2}{|l|}{ Adjusted to MetS } \\
\hline TSH 2.50-4.94 $(\mu \mathrm{IU} / \mathrm{mL})$ & $1.45(1.16-1.80)<0.001$ \\
\hline TSH 4.95-9.99 ( $(\mathrm{IIU} / \mathrm{mL})$ & $1.34(0.82-2.19) 0.247$ \\
\hline $\mathrm{TSH} \geq 10(\mu \mathrm{IU} / \mathrm{mL})$ & $9.33(3.11-27.97)<0.001$ \\
\hline \multicolumn{2}{|l|}{ Adjusted to MetS parameters ** } \\
\hline TSH 2.50-4.94 ( $\mu \mathrm{IU} / \mathrm{mL})$ & $1.31(1.00-1.71) 0.046$ \\
\hline TSH 4.95-9.99 $(\mu \mathrm{IU} / \mathrm{mL})$ & $1.14(0.63-2.06) 0.655$ \\
\hline $\mathrm{TSH} \geq 10(\mu \mathrm{IU} / \mathrm{mL})$ & $8.22(1.77-38.04) 0.007$ \\
\hline \multicolumn{2}{|c|}{$\begin{array}{l}\text { Note: Control reference group for the analysis TSH }<2.5(\mu \mathrm{IU} / \mathrm{mL}){ }^{*}{ }^{*} \text { All multivariate analyses were adjusted } \\
\text { also for age, sex and alcohol consumption. }{ }^{* *} \text { MetS parameters: WC }>88 \mathrm{~W} / 102 \mathrm{M} \mathrm{cm} ; \mathrm{TG} \geq 150 \mathrm{mg} / \mathrm{dL} \\
\mathrm{HDL}<50 \mathrm{~W} / 40 \mathrm{M} \mathrm{mg} / \mathrm{dL} ; \mathrm{BP} \geq 130 / 85 \mathrm{mmHg} \text {; Glyc } \geq 100 \mathrm{mg} / \mathrm{dL} \text {. Abbreviations: MetS, metabolic syndrome } \\
\mathrm{FLI} \text { fatty liver index; THH, thyroid stimulating hormone; WC, waist circumference; TG, triglycerides; HDL, } \\
\text { high-density lipoprotein; BP, blood pressure; Glyc, glycemia. }\end{array}$} \\
\hline
\end{tabular}

\subsection{Relationship between TSH and Hypertransaminasemia}

The prevalence of hypertransaminasemia (ALT and/or AST > $35 \mathrm{U} / \mathrm{L}$ ) increased from $12 \%$, in subjects with TSH $<2.5 \mu \mathrm{IU} / \mathrm{mL}$, to $15 \%$ in subjects with TSH $\geq 2.5 \mu \mathrm{IU} / \mathrm{mL}$ or $26 \%$ when TSH $\geq 10 \mu \mathrm{IU} / \mathrm{mL}$, in a significant way ( $p=0.036$ and $p=0.040$, respectively). ALT and ALP values underwent a dose-dependent increase in relation to TSH levels (Table 1).

The risk of presenting hypertransaminasemia when $\mathrm{TSH} \geq 2.5 \mu \mathrm{IU} / \mathrm{mL}$ was higher compared to the control group, and independent of age, sex, obesity, cholesterol, MetS, or MetS parameters (Figure 2b). In the multivariate analyses of model 2, the subjects with TSH 2.50-4.94 $\mu \mathrm{IU} / \mathrm{mL}$ presented an increased risk of hypertransaminasemia of 1.34 times, compared to the control group, independently of the different parameters of MetS $(p=0.035)$. Furthermore, the risk of ALT and/or AST $>35 \mathrm{U} / \mathrm{L}$ in subjects with $\mathrm{TSH} \geq 10 \mu \mathrm{IU} / \mathrm{mL}$ was 2.24 times higher compared to the TSH $<2.5 \mu \mathrm{IU} / \mathrm{mL}$ group, although these results were not significant (Table 4). 
Table 4. Analysis between TSH group and risk of hypertransaminasemia.

\begin{tabular}{cc}
\hline & ALT and/or AST $>$ 35 U/L \\
\hline Univariate & OR (CI 95\%) $p$-value \\
\hline TSH 2.50-4.94 $(\mu \mathrm{IU} / \mathrm{mL})$ & $1.33(1.03-1.71) 0.031$ \\
TSH 4.95-9.99 $(\mu \mathrm{IU} / \mathrm{mL})$ & $0.88(0.45-1.72) 0.709$ \\
TSH $\geq 10(\mu \mathrm{IU} / \mathrm{mL})$ & $2.70(0.96-7.59) 0.059$ \\
\hline Multivariate * & \\
TSH 2.50-4.94 $(\mu \mathrm{IU} / \mathrm{mL})$ & $1.34(1.02-1.75) 0.035$ \\
TSH 4.95-9.99 $(\mu \mathrm{IU} / \mathrm{mL})$ & $0.98(0.49-1.97) 0.962$ \\
TSH $\geq 10(\mu \mathrm{IU} / \mathrm{mL})$ & $2.24(0.76-6.61) 0.145$ \\
\hline
\end{tabular}

Note: Control reference group for the analysis TSH $<2.5(\mu \mathrm{IU} / \mathrm{mL}) .{ }^{*}$ Adjusting for age, sex, alcohol consumption and different parameters of MetS (WC $>88 \mathrm{~W} / 102 \mathrm{M} \mathrm{cm}$; TG $\geq 150 \mathrm{mg} / \mathrm{dL} ; \mathrm{HDL}<50 \mathrm{~W} / 40 \mathrm{M}$ $\mathrm{mg} / \mathrm{dL} ; \mathrm{BP} \geq 130 / 85 \mathrm{mmHg}$; Glyc $\geq 100 \mathrm{mg} / \mathrm{dL}$ ). Abbreviations: ALT, alanine aminotransferase; AST, aspartate aminotransferase; TSH, thyroid stimulating hormone; MetS, metabolic syndrome; WC, waist circumference; TG, triglycerides; HDL, high-density lipoprotein; BP, blood pressure; Glyc, glycemia.

\subsection{Association between TSH and Liver Fibrosis}

LS values increased with TSH levels: from $4.8 \pm 1.7 \mathrm{kPa}$ in the group with $\mathrm{TSH}<2.5 \mu \mathrm{IU} / \mathrm{mL}$ to $5.1 \pm 2.7 \mathrm{kPa}$ in subjects with $\mathrm{TSH} \geq 2.5 \mu \mathrm{IU} / \mathrm{mL}(p=0.003)$. A significant increase in LS was also observed in the group with TSH $\geq 10 \mu \mathrm{IU} / \mathrm{mL}$ (LS $5.3 \pm 1.8 \mathrm{kPa}, p=0.017$ ).

Regarding the prevalence of fibrosis, as seen in Figure 3, higher values are reached in all TSH groups compared to the control group. Some $7.1 \%$ and $4.3 \%$ of the subjects with TSH $\geq 2.5 \mu \mathrm{IU} / \mathrm{mL}$ obtained TE values $\geq 8.0 \mathrm{kPa}$ and $\geq 9.2 \mathrm{kPa}$, respectively, higher than the control group. Furthermore, in subjects with TSH $\geq 10 \mu \mathrm{IU} / \mathrm{mL}$, the prevalence of fibrosis was higher: Some $10.5 \%$ vs. $4.3 \%$ (control group) for TE values $\geq 8.0 \mathrm{kPa}$; and $5.3 \%$ vs. $2.0 \%$ (control group) for TE values $\geq 9.2 \mathrm{kPa}$. All of these findings were statistically significant.

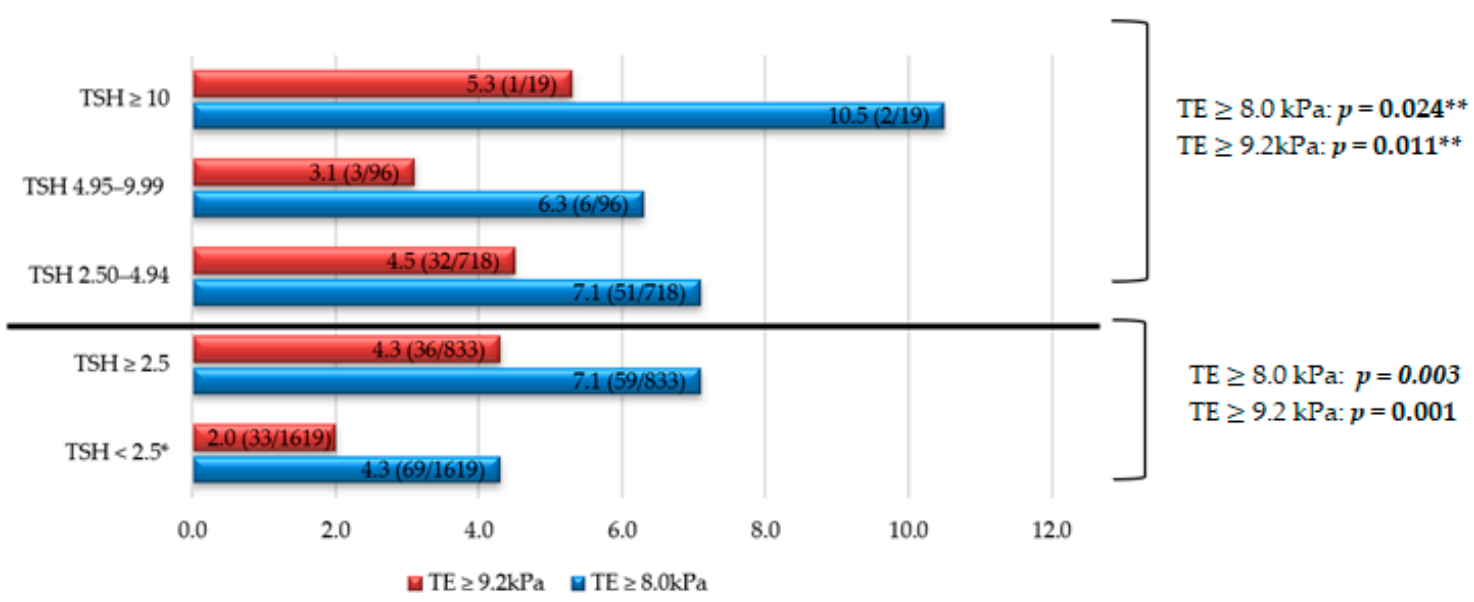

Figure 3. Liver fibrosis prevalence according to TSH levels in different groups. Note: The data are expressed in \%. * Comparison/control group. ${ }^{* *} p$ trend, comparing four groups of TSH: $<2.5,2.50-4.94,4.95-9.99, \geq 10 \mu \mathrm{IU} / \mathrm{mL}$. TSH units: $\mu \mathrm{IU} / \mathrm{mL}$. Abbreviations: TE, transient elastography; TSH, thyroid stimulating hormone.

The risk of fibrosis, at both TE cut-off points, in subjects with TSH $\geq 2.5 \mu \mathrm{IU} / \mathrm{mL}$ was higher when compared to the group with TSH $<2.5 \mu \mathrm{IU} / \mathrm{mL}$, regardless of age, sex, obesity, cholesterol, and MetS (Figure 4). Subjects with TSH $\geq 2.5 \mu \mathrm{IU} / \mathrm{mL}$ showed an increased risk of fibrosis of 1.67 (Figure $4 a$ ) and 2.17 times (Figure $4 b$ ) for the cut-off points $\mathrm{TE} \geq 8.0 \mathrm{kPa}$ and $\geq 9.2 \mathrm{kPa}$ respectively and independent of the different parameters of MetS. 
(a)

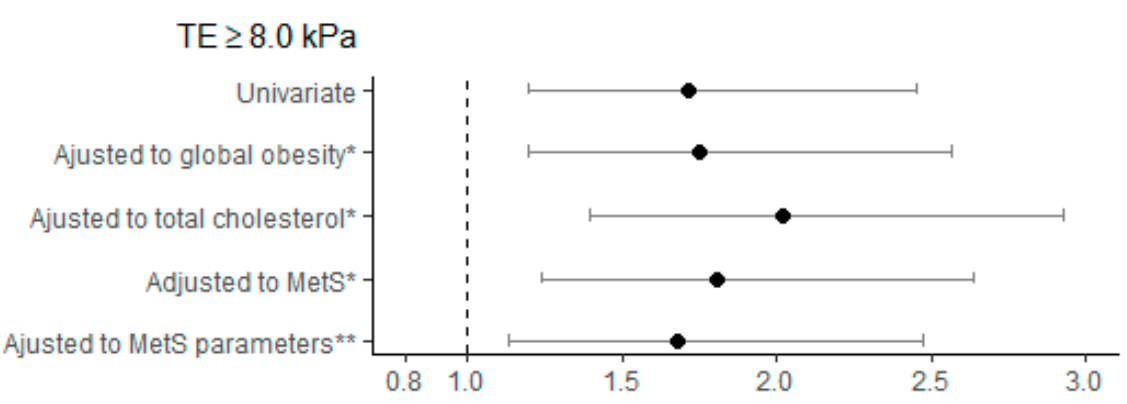

(b)

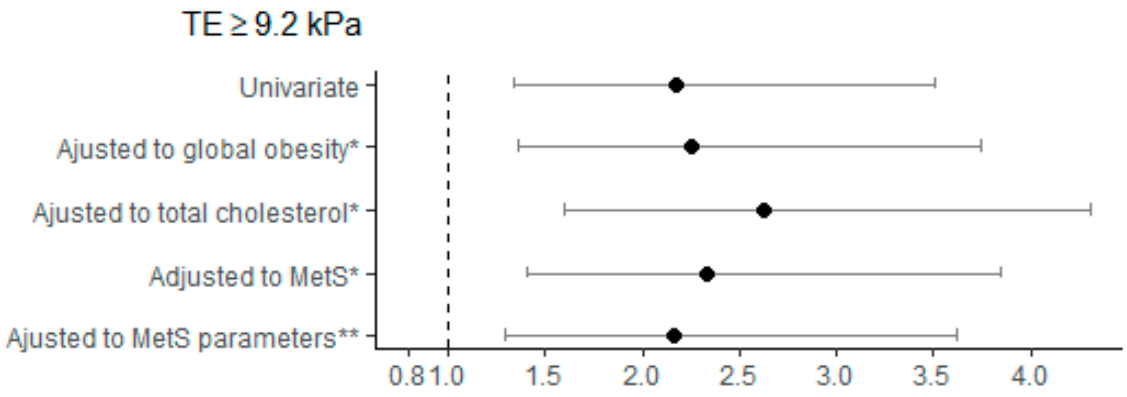

OR (Cl $95 \%)$ p-value

$1.71(1.20-2.45) \quad 0.003$

$1.75(1.20-2.56) \quad 0.004$

$2.02(1.39-2.93)<0.001$

$1.81(1.24-2.64) \quad 0.002$

$1.67(1.13-2.47) \quad 0.009$

OR (Cl $95 \%)$ p-value

$2.17(1.34-3.51) \quad 0.002$

$2.26(1.36-3.74) \quad 0.002$

$2.63(1.60-4.31)<0.001$

$2.33(1.41-3.85) \quad 0.001$

$2.17(1.30-3.62) \quad 0.003$

Figure 4. Liver fibrosis risk, using two transient elastography cut-offs, TE $\geq 8.0 \mathrm{kPa}$ in (a) and TE $\geq 9.2 \mathrm{kPa}$ in (b), as dependent variables, in TSH group $\geq 2.5(\mu \mathrm{IU} / \mathrm{mL})$, adjusted to different metabolic factors. Note: Control reference group for the analysis TSH $<2.5(\mu \mathrm{IU} / \mathrm{mL}) .{ }^{*}$ All multivariate analyses were adjusted also for age, sex and alcohol consumption. ${ }^{* *}$ MetS parameters: WC > $88 \mathrm{~W} / 102 \mathrm{M} \mathrm{cm}$; TG $\geq 150 \mathrm{mg} / \mathrm{dL} ; \mathrm{HDL}<50 \mathrm{~W} / 40 \mathrm{M} \mathrm{mg} / \mathrm{dL} ; \mathrm{BP} \geq 130 / 85 \mathrm{mmHg}$; Glyc $\geq 100 \mathrm{mg} / \mathrm{dL}$. Abbreviations: MetS, metabolic syndrome; TE, transient elastography; TSH, thyroid stimulating hormone; WC, waist circumference; TG, triglycerides; HDL, high-density lipoprotein; BP, blood pressure; Glyc, glycemia.

Likewise, in the multivariate analyses carried out with the different TSH groups (model 2), an increased risk of fibrosis was determined, both in TE $\geq 8.0 \mathrm{kPa}$ and $\geq 9.2 \mathrm{kPa}$, in subjects with TSH $2.50-4.94 \mu \mathrm{IU} / \mathrm{mL}$, significantly and independently of all the confounding factors studied (Table 5). Although in the TSH groups with higher levels an increased risk of fibrosis was also observed for both cut-off points, these findings were not significant for the TSH 4.95-9.99 $\mu \mathrm{IU} / \mathrm{mL}$ groups or for TSH $\geq 10 \mu \mathrm{IU} / \mathrm{mL}$, with the exception of the analysis adjusted for total cholesterol.

Table 5. Analysis of liver fibrosis risk, using two elastography cut-offs as dependent variables, according to TSH group. Four different multivariate logistic regression models, adjusting for obesity, cholesterol, MetS and MetS parameters.

\begin{tabular}{ccc}
\hline & TE $\geq \mathbf{8 . 0} \mathbf{~ k P a}$ & TE $\geq \mathbf{9 . 2} \mathbf{~ k P a}$ \\
\hline OR $(\mathrm{CI}$ 95\%) $p$-value & OR $(\mathrm{CI}$ 95\%) $p$-value \\
\hline Univariate & & \\
\hline TSH 2.50-4.94 $(\mu \mathrm{IU} / \mathrm{mL})$ & $1.72(1.18-2.49) 0.004$ & $2.24(1.37-3.68) 0.001$ \\
TSH 4.95-9.99 $(\mu \mathrm{IU} / \mathrm{mL})$ & $1.50(0.63-3.54) 0.358$ & $1.55(0.47-5.15) 0.474$ \\
TSH $\geq 10(\mu \mathrm{IU} / \mathrm{mL})$ & $2.64(0.60-11.67) 0.200$ & $2.67(0.35-20.6) 0.346$ \\
\hline Multivariate * & & \\
\hline Adjusted to global obesity & & \\
TSH 2.50-4.94 $(\mu \mathrm{IU} / \mathrm{mL})$ & $1.74(1.17-2.58) 0.006$ & $2.30(1.37-3.87) 0.002$ \\
TSH 4.95-9.99 $(\mu \mathrm{IU} / \mathrm{mL})$ & $1.72(0.69-4.25) 0.243$ & $1.82(0.52-6.36) 0.346$ \\
TSH $\geq 10(\mu \mathrm{IU} / \mathrm{mL})$ & $2.39(0.50-11.37) 0.272$ & $2.44(0.29-20.27) 0.410$ \\
\hline
\end{tabular}


Table 5. Cont.

\begin{tabular}{ccc}
\hline & TE $\geq \mathbf{8 . 0} \mathbf{~ k P a}$ & TE $\geq \mathbf{9 . 2 ~ k P a}$ \\
\hline Adjusted to total cholesterol & & \\
TSH 2.50-4.94 $(\mu \mathrm{IU} / \mathrm{mL})$ & $1.98(1.34-2.90)<0.001$ & $2.64(1.59-4.39)<0.001$ \\
TSH 4.95-9.99 $(\mu \mathrm{IU} / \mathrm{mL})$ & $2.00(0.83-4.86) 0.124$ & $2.15(0.63-7.32) 0.222$ \\
TSH $\geq 10(\mu \mathrm{IU} / \mathrm{mL})$ & $5.01(1.10-22.85) 0.037$ & $5.44(0.68-43.54) 0.111$ \\
\hline Adjusted to MetS & & \\
TSH 2.50-4.94 $(\mu \mathrm{IU} / \mathrm{mL})$ & $1.76(1.19-2.61) 0.005$ & $2.32(1.39-3.88) 0.001$ \\
TSH 4.95-9.99 $(\mu \mathrm{IU} / \mathrm{mL})$ & $1.94(0.79-4.75) 0.147$ & $2.17(0.63-7.51) 0.220$ \\
TSH $\geq 10(\mu \mathrm{IU} / \mathrm{mL})$ & $3.34(0.71-15.78) 0.128$ & $3.54(0.43-29.37) 0.241$ \\
\hline Adjusted to MetS parameters $* *$ & & \\
TSH 2.50-4.94 $(\mu \mathrm{IU} / \mathrm{mL})$ & $1.64(1.10-2.46) 0.016$ & $2.17(1.28-3.68) 0.004$ \\
TSH 4.95-9.99 $(\mu \mathrm{IU} / \mathrm{mL})$ & $1.78(0.72-4.44) 0.213$ & $2.00(0.57-7.02) 0.277$ \\
TSH $\geq 10(\mu \mathrm{IU} / \mathrm{mL})$ & $2.46(0.50-12.09) 0.269$ & $2.66(0.31-22.98) 0.375$ \\
\hline
\end{tabular}

Note: Control reference group for the analysis TSH $<2.5(\mu \mathrm{IU} / \mathrm{mL}) .{ }^{*}$ All multivariate analyses were adjusted also for age, sex and alcohol consumption. ${ }^{* *}$ MetS parameters: $\mathrm{WC}>88 \mathrm{~W} / 102 \mathrm{M} \mathrm{cm}$; TG $\geq 150 \mathrm{mg} / \mathrm{dL}$; $\mathrm{HDL}<50 \mathrm{~W} / 40 \mathrm{M} \mathrm{mg} / \mathrm{dL} ; \mathrm{BP} \geq 130 / 85 \mathrm{mmHg}$; Glyc $\geq 100 \mathrm{mg} / \mathrm{dL}$. Abbreviations: MetS, metabolic syndrome; TE, transient elastography; TSH, thyroid stimulating hormone; WC, waist circumference; TG, triglycerides; HDL, high-density lipoprotein; BP, blood pressure; Glyc, glycemia.

\section{Discussion}

The findings of this study demonstrate the association between TSH levels, NAFLD, and liver fibrosis. Specifically, those subjects with TSH levels $\geq 2.5 \mu \mathrm{IU} / \mathrm{mL}$ have a significantly increased risk of presenting NAFLD and fibrosis independently of the different metabolic factors studied.

The relationship between thyroid function or TH and NAFLD was analyzed in several studies in the last decade. There are multiple differences in the methodology used to study both pathologies. Thus, there are studies that have used serological markers, such as FLI, for the diagnosis of NAFLD [21], while others have used abdominal ultrasound [13] or pathological criteria [22]. The most accepted upper limit of TSH to define normality of thyroid function is between 4 and $5 \mu \mathrm{IU} / \mathrm{mL}$ [23], although there are authors who differentiate subjects with an upper limit of normality of TSH $<2.5 \mu \mathrm{IU} / \mathrm{mL}$ as those with strictly normal thyroid function [24]. Other factors, such as race, the presence of antithyroid antibodies, or the percentage of patients undergoing hormone replacement therapy, also influence the variability of the studies carried out.

Some studies have shown higher TSH levels [10] or a higher prevalence of hypothyroidism [25] in subjects with NAFLD. A study was recently published, with a large sample of subjects, which shows a higher incidence of hypothyroidism and autoimmune thyroiditis in the group with NAFLD, with a follow-up period of 10 years [26]. Other studies confirm an increased risk of presenting NAFLD based on TSH levels [27] or thyroid function [28]. Low T4 [29] or high T3 [30] levels have been correlated with liver steatosis. Furthermore, TSH levels have also been linked to NASH [31]. Likewise, there are studies that have demonstrated these associations independently of MetS [32] and, on the other hand, others that have not [33].

Furthermore, the relationship between TH and NAFLD has also been studied in specific subpopulations according to some metabolic conditioning factors. In the morbidly obese population, an increased risk of NAFLD, defined by serological markers, has been found in subjects with higher TSH and T3 values [34]. Higher TSH levels, lower T4 levels and a higher prevalence of positivity of anti-thyroid peroxidase antibodies were found in patients where T2DM and NAFLD coexist, compared to those without NAFLD [35]. In another similar study, carried out in a diabetic and euthyroid population, it was shown that subjects with higher levels of T3 and TSH had a higher risk of presenting NAFLD, with ORs of 3.02 and 1.58, respectively [36].

The meta-analyses available to date show some different results. In one by Guo et al., where 26 studies were included, the subjects with NAFLD/NASH reached significantly 
higher levels of TSH in relation to the control group. In addition, a 1.6 times increased risk of NAFLD was also demonstrated in hypothyroid subjects [37]. Along the same lines, Mantovani et al. demonstrated the association between hypothyroidism and NAFLD independently of age, sex, BMI, and other metabolic factors studied, in a study involving 44,140 individuals [38]. He et al. also found an increased risk of NAFLD of 1.81 and 1.63 times in subjects with overt and subclinical hypothyroidism, respectively [39]. In contrast, the study by Jaruvongvanich et al. did not demonstrate a relationship between thyroid hormones (TSH, T4, T3) and NAFLD, nor with hypothyroidism [40]. The findings of our study are in line with the above. On the one hand, we found a correlation between NAFLD and TSH levels; on the other hand, a higher prevalence of NAFLD in subjects with higher TSH and lastly, an increased risk of NAFLD of 1.5 times in subjects with TSH $\geq 2.5 \mu \mathrm{IU} / \mathrm{mL}$ independently of MetS. This last finding is of interest because it shows a higher risk of NAFLD in patients with TSH levels that are within normal parameters.

Although there is still some controversy in the relationship between TH and NAFLD, it is plausible to think that both entities are linked, either by a direct effect of TH or by an effect mediated by the components of MetS. A low thyroid function is associated with increases in cholesterol and TG levels, and with greater weight gain, which in turn are risk factors for the development of NAFLD [41]. We have demonstrated these same findings in our study. At the pathophysiological level, THs participate in intrahepatic lipolysis, through the activation of autophagy, and the beta oxidation of fatty acids [42], but when there is a low thyroid function, the activity of hepatic lipases decreases which entails accumulation of TG in hepatocytes [43]. Furthermore, it has been shown that, in hypothyroid subjects, adipocytokine levels are altered [44], which can contribute to liver inflammation processes. THs have also been linked to the regulation of micro-RNAs [45] and to some genetic polymorphisms related to NAFLD. For example, a recent study has shown that there is a significant association between euthyroid subjects with high-normal TSH (2.5 to $5.3 \mu \mathrm{IU} / \mathrm{mL}$ ) and NASH, when they carry the risk of allele of PNPLA3 G [46].

THs have been correlated with moderate elevations in transaminase levels. In an observational study in our setting, where 10,116 subjects were included, it was found that the alteration in AST levels affected subjects with TSH $\geq 10 \mu \mathrm{IU} / \mathrm{mL}$ more frequently and significantly; it was also more prevalent in subjects with low T4 levels [41]. Along the same lines, Chung et al. demonstrated the association between alteration of ALT $>33 / 25$ (men/women) and thyroid function, affecting $20.1 \%$ of subjects with subclinical hypothyroidism and $25.9 \%$ in clinical hypothyroidism [10]. Furthermore, ALT levels have also been linked to MetS [47]. Similarly, our study found a 1.32 times increased risk of having hypertransaminasemia in subjects with TSH $\geq 2.5 \mu \mathrm{IU} / \mathrm{mL}$, regardless of MetS parameters. Although hypertransaminasemia is not a good predictive marker of NAFLD, since there may be steatosis with normal liver function, we believe that the relationship found between TH and hypertransaminasemia is due to the association with NAFLD.

Moreover, the role of TH in liver fibrosis has also been discussed. At the pathophysiological level, it is speculated that TH may be involved in the activation of stellate liver cells, a crucial step in the development of liver fibrosis [48]. In the same way as the studies that relate thyroid function and NAFLD, in this case, the methods used for the diagnosis of liver fibrosis are also different. While some authors use serological markers [34,49], others use TE [50] or liver biopsy [51]. In our case, we used TE, which has a high sensitivity and specificity and is the usual screening method in our setting. The findings that we encountered are similar to those present in the literature. Bano et al. found that higher TSH levels were associated with a 1.49 times increased risk of liver fibrosis, using TE values $\geq 8.0 \mathrm{kPa}$ as the cut-off point [50]. Kim et al. also found a relationship between low thyroid function and liver fibrosis, using serological markers [49]. In another recent study, low-normal thyroid function was associated with TE values $\geq 8.0 \mathrm{kPa}$ and $\geq 9.2 \mathrm{kPa}$, in euthyroid subjects, dependent on other metabolic factors [52]. Along the same lines, in a recently published meta-analysis, hypothyroidism, both sub-clinical and overt, was associated with an increased risk of liver fibrosis with OR $>2$ [53]. In our study, we found 
an independent relationship of MetS parameters between subjects with TSH $\geq 2.5 \mu \mathrm{IU} / \mathrm{mL}$ and liver fibrosis. Still, these findings need to be confirmed in prospective studies.

Based on this evidence, in recent years it has been proposed to consider TH or the thyroid hormone receptor (THR) as therapeutic targets for NAFLD. In a population study with dyslipidemia and sub-clinical hypothyroidism, the use of low doses of levothyroxine decreased the prevalence of NAFLD [54]. In another, a 12\% reduction in intrahepatic lipids was demonstrated in subjects with NAFLD and T2DM when using levothyroxine [55]. Treatments with agonists of THR- $\beta$, which is the main receptor for TH in the liver, have also been tried to reduce cholesterol levels [56] or for the treatment of non-alcoholic steatohepatitis [57]. Even so, no treatment has yet been approved for NAFLD and nonpharmacological measures aimed at controlling metabolic factors continue to be the gold standard in the treatment of these patients.

Finally, this study has some limitations. The gold standard method for the diagnosis of NAFLD and liver fibrosis is liver biopsy, but as it is an invasive test, it is not performed in routine clinical practice [4]. In this specific case, validated serological markers have been used for the diagnosis of NAFLD and liver stiffness measurements using transient liver elastography for the diagnosis of fibrosis. Furthermore, the recommended probe to measure liver stiffness in obese subjects is the $\mathrm{XL}$, but in our study all the examinations were performed with the $\mathrm{M}$ probe as it was the only probe available. Due to the design of the reference cohort used, we do not know the percentage of subjects who were being treated with hormone replacement therapy, and we do not have information on T4 or T3 levels, the presence of antithyroid antibodies or the previous diagnosis of thyroid cancer. Finally, the cross-sectional design of this study does not allow for determining causal relationships.

\section{Conclusions}

In conclusion, the findings of this study demonstrate that TSH levels $\geq 2.5 \mu \mathrm{IU} / \mathrm{mL}$ are associated with a higher risk of NAFLD and liver fibrosis in the general population, independently of the MetS parameters. Furthermore, individuals with TSH $\geq 10 \mu \mathrm{IU} / \mathrm{mL}$ have an additional increased risk of NAFLD. Although more prospective design studies are required, we propose the need for stricter control of TSH levels in those subjects with coexisting metabolic risk factors for developing NAFLD and liver fibrosis.

Author Contributions: Conceptualization, A.M.-E. and L.C.; methodology, A.M.-E., G.P. and L.C.; validation, A.M.-E., G.P., P.T.-M. and L.C.; investigation, A.M.-E., L.R., I.A. and C.E.-M.; supervision, A.M.-E., L.R., I.A. and C.E.-M.; formal analysis and data curation, G.P. and A.C.-G.; writing-original draft preparation, A.M.-E.; writing-review and editing, A.M.-E. and L.C.; funding acquisition, P.T.-M. and L.C. All authors have read and agreed to the published version of the manuscript.

Funding: This study is part of the project "High Prevalence of Liver Fibrosis Among European Adults With Unknown Liver Disease: A Population-Based Study" and obtained funding from the Carlos III Institute of Health, Ministry of Economy and Competitiveness (Spain), awarded on the 2011 call under the Health Strategy Action 2013-2016, within the National Research Program oriented to Societal Challenges, with reference PI11/0267 (PI Llorenç Caballería). Alba Martínez-Escudé received a predoctoral and research grant from IDIAP Jordi Gol 2017 and 2020.

Institutional Review Board Statement: The protocol was approved by the Ethics Committee of IDIAP Jordi Gol Institute with reference P11/58. The study was conducted according to the guidelines of the Declaration of Helsinki and the data were treated according to the state data protection law.

Informed Consent Statement: Informed consent was obtained from all subjects involved in the study.

Data Availability Statement: Data sharing not applicable.

Conflicts of Interest: The authors declare no conflict of interest. 


\section{References}

1. Bellentani, S. The epidemiology of non-alcoholic fatty liver disease. Liver Int. 2017, 37 (Suppl. S1), 81-84. [CrossRef] [PubMed]

2. Younossi, Z.M. Non-alcoholic fatty liver disease-A global public health perspective. J. Hepatol. 2019, 70, 531-544. [CrossRef]

3. Eslam, M.; Newsome, P.N.; Sarin, S.K.; Anstee, Q.M.; Targher, G.; Romero-Gomez, M.; Zelber-Sagi, S.; Wong, V.W.-S.; Dufour, J.-F.; Schattenberg, J.M.; et al. A new definition for metabolic dysfunction-associated fatty liver disease: An international expert consensus statement. J. Hepatol. 2020, 73, 202-209. [CrossRef]

4. Chalasani, N.; Younossi, Z.; Lavine, J.E.; Charlton, M.; Cusi, K.; Rinella, M.; Harrison, S.A.; Brunt, E.M.; Sanyal, A.J. The diagnosis and management of nonalcoholic fatty liver disease: Practice guidance from the American Association for the Study of Liver Diseases. Hepatology 2018, 67, 328-357. [CrossRef]

5. $\quad$ Brunt, E.M.; Kleiner, D.E.; Carpenter, D.H.; Rinella, M.; Harrison, S.A.; Loomba, R.; Younossi, Z.; Neuschwander-Tetri, B.A.; Sanyal, A.J.; the American Association for the Study of Liver Diseases NASH Task Force. NAFLD: Reporting Histologic Findings in Clinical Practice. Hepatology 2021, 73, 2028-2038. [CrossRef] [PubMed]

6. Diehl, A.M.; Day, C. Cause, Pathogenesis, and Treatment of Nonalcoholic Steatohepatitis. N. Engl. J. Med. 2017, 377, $2063-2072$. [CrossRef] [PubMed]

7. Rosato, V.; Masarone, M.; Dallio, M.; Federico, A.; Aglitti, A.; Persico, M. NAFLD and Extra-Hepatic Comorbidities: Current Evidence on a Multi-Organ Metabolic Syndrome. Int. J. Environ. Res. Public Health 2019, 16, 3415. [CrossRef]

8. Tanase, D.M.; Gosav, E.M.; Neculae, E.; Costea, C.F.; Ciocoiu, M.; Hurjui, L.L.; Tarniceriu, C.C.; Floria, M. HypothyroidismInduced Nonalcoholic Fatty Liver Disease (HIN): Mechanisms and Emerging Therapeutic Options. Int. J. Mol. Sci. 2020, $21,5927$. [CrossRef]

9. Pagadala, M.R.; Zein, C.O.; Dasarathy, S.; Yerian, L.M.; Lopez, R.; McCullough, A.J. Prevalence of Hypothyroidism in Nonalcoholic Fatty Liver Disease. Dig. Dis. Sci. 2012, 57, 528-534. [CrossRef]

10. Chung, G.E.; Kim, D.; Kim, W.; Yim, J.Y.; Park, M.J.; Kim, Y.J.; Yoon, J.-H.; Lee, H.-S. Non-alcoholic fatty liver disease across the spectrum of hypothyroidism. J. Hepatol. 2012, 57, 150-156. [CrossRef] [PubMed]

11. Gu, Y.; Wu, X.; Zhang, Q.; Liu, L.; Meng, G.; Wu, H.; Zhang, S.; Wang, Y.; Zhang, T.; Wang, X.; et al. High-Normal Thyroid Function Predicts Incident Nonalcoholic Fatty Liver Disease Among Middle-Aged and Older Euthyroid Subjects. J. Gerontol. Ser. A Biol. Sci. Med. Sci. 2021, glab037. [CrossRef]

12. Zhang, X.; Zhang, J.; Dai, Y.; Qin, J. Serum Thyroid Hormones Levels are Significantly Associated with Nonalcoholic Fatty Liver Disease in Euthyroid Chinese Population. Clin. Lab. 2020, 66. [CrossRef]

13. Eshraghian, A.; Dabbaghmanesh, M.H.; Eshraghian, H.; Fattahi, M.R.; Omrani, G.R. Nonalcoholic fatty liver disease in a cluster of Iranian population: Thyroid status and metabolic risk factors. Arch. Iran. Med. 2013, 16, 584-589.

14. Lee, K.W.; Bang, K.B.; Rhee, E.J.; Kwon, H.J.; Lee, M.Y.; Cho, Y.K. Impact of hypothyroidism on the development of non-alcoholic fatty liver disease: A 4-year retrospective cohort study. Clin. Mol. Hepatol. 2015, 21, 372-378. [CrossRef]

15. Caballería, L.; Pera, G.; Arteaga, I.; Rodríguez, L.; Alumà, A.; Morillas, R.M.; de la Ossa, N.; Díaz, A.; Expósito, C.; Miranda, D.; et al. High Prevalence of Liver Fibrosis Among European Adults With Unknown Liver Disease: A Population-Based Study. Clin. Gastroenterol. Hepatol. 2018, 16, 1138-1145.e5. [CrossRef]

16. Ascaso, J.F.; Millán, J.; Hernández-Mijares, A.; Blasco, M.; Brea, Á.; Díaz, Á.; Pedro-Botet, J.; Pintó, X. Dislipidemia aterogénica 2019. Consensus document of the Atherogenic Dyslipidaemia Group of the Spanish Arteriosclerosis Society. Clin. Investig. Arterioscler. 2020, 32, 120-125. [CrossRef]

17. Julián, M.T.; Pera, G.; Soldevila, B.; Caballería, L.; Julve, J.; Puig-Jové, C.; Morillas, R.; Torán, P.; Expósito, C.; Puig-Domingo, M.; et al. Atherogenic dyslipidemia, but not hyperglycemia, is an independent factor associated with liver fibrosis in subjects with type 2 diabetes and NAFLD: A population-based study. Eur. J. Endocrinol. 2021, 184, 587-596. [CrossRef]

18. National Cholesterol Education Program (NCEP); Expert Panel on Detection, Evaluation, and Treatment of High Blood Cholesterol in Adults (Adult Treatment Panel III). Third Report of the National Cholesterol Education Program (NCEP) Expert Panel on Detection, Evaluation, and Treatment of High Blood Cholesterol in Adults (Adult Treatment Panel III) final report. Circulation 2002, 106, 3143-3421. [CrossRef]

19. Bedogni, G.; Bellentani, S.; Miglioli, L.; Masutti, F.; Passalacqua, M.; Castiglione, A.; Tiribelli, C. The Fatty Liver Index: A simple and accurate predictor of hepatic steatosis in the general population. BMC Gastroenterol. 2006, 6, 33. [CrossRef]

20. Castera, L.; Friedrich-Rust, M.; Loomba, R. Noninvasive Assessment of Liver Disease in Patients with Nonalcoholic Fatty Liver Disease. Gastroenterology 2019, 156, 1264-1281.e4. [CrossRef]

21. Berg, E.H.V.D.; van Tienhoven-Wind, L.J.; Amini, M.; Schreuder, T.C.; Faber, K.N.; Blokzijl, H.; Dullaart, R.P. Higher free triiodothyronine is associated with non-alcoholic fatty liver disease in euthyroid subjects: The Lifelines Cohort Study. Metabolism 2017, 67, 62-71. [CrossRef] [PubMed]

22. Carulli, L.; Ballestri, S.; Lonardo, A.; Lami, F.; Violi, E.; Losi, L.; Bonilauri, L.; Verrone, A.M.; Odoardi, M.R.; Scaglioni, F.; et al. Is nonalcoholic steatohepatitis associated with a high-though-normal thyroid stimulating hormone level and lower cholesterol levels? Intern. Emerg. Med. 2011, 8, 297-305. [CrossRef] [PubMed]

23. Feldt-Rasmussen, U.; Klose, M. Clinical Strategies in the Testing of Thyroid Function. Available online: https://www.ncbi.nlm. nih.gov/books/NBK285558/ (accessed on 20 November 2020). 
24. Baloch, Z.; Carayon, P.; Conte-Devolx, B.; Demers, L.M.; Feldt-Rasmussen, U.; Henry, J.-F.; LiVosli, A.V.; Niccoli-Sire, P.; John, R.; Ruf, J.; et al. Laboratory medicine practice guidelines. Laboratory support for the diagnosis and monitoring of thyroid disease. Thyroid 2003, 13, 3-126. [CrossRef] [PubMed]

25. Parikh, P.; Phadke, A.; Sawant, P. Prevalence of hypothyroidism in nonalcoholic fatty liver disease in patients attending a tertiary hospital in western India. Indian J. Gastroenterol. 2015, 34, 169-173. [CrossRef]

26. Loosen, S.H.; Demir, M.; Kostev, K.; Luedde, T.; Roderburg, C. Incidences of hypothyroidism and autoimmune thyroiditis are increased in patients with nonalcoholic fatty liver disease. Eur. J. Gastroenterol. Hepatol. 2021. [CrossRef]

27. Tahara, K.; Akahane, T.; Namisaki, T.; Moriya, K.; Kawaratani, H.; Kaji, K.; Takaya, H.; Sawada, Y.; Shimozato, N.; Sato, S.; et al. Thyroid-stimulating hormone is an independent risk factor of non-alcoholic fatty liver disease. JGH Open 2019, 4, 400-404. [CrossRef]

28. Lee, J.; Ha, J.; Jo, K.; Lim, D.-J.; Lee, J.-M.; Chang, S.-A.; Kang, M.-I.; Cha, B.-Y.; Kim, M.-H. Male-specific association between subclinical hypothyroidism and the risk of non-alcoholic fatty liver disease estimated by hepatic steatosis index: Korea National Health and Nutrition Examination Survey 2013 to 2015. Sci. Rep. 2018, 8, 15145. [CrossRef]

29. Tao, Y.; Gu, H.; Wu, J.; Sui, J. Thyroid function is associated with non-alcoholic fatty liver disease in euthyroid subjects. Endocr. Res. 2015, 40, 74-78. [CrossRef]

30. Liu, G.; Zheng, X.; Guan, L.; Jiang, Z.; Lin, H.; Jiang, Q.; Zhang, N.; Zhang, Y.; Zhang, X.; Yu, C.; et al. Free triiodothyronine levels are positively associated with non-alcoholic fatty liver disease in euthyroid middle-aged subjects. Endocr. Res. 2014, 40, 188-193. [CrossRef]

31. Liu, L.; Li, P.; Mi, Y.; Liu, Y.; Liu, Y.; Zhang, P. Thyroid-stimulating hormone is associated with nonalcoholic steatohepatitis in patients with chronic hepatitis B. Medicine 2019, 98, e17945. [CrossRef]

32. Grewal, H.; Joshi, S.; Sharma, R.; Mittal, P.; Goel, A. Non-alcoholic fatty liver disease in patients with hypothyroidism presenting at a rural tertiary care centre in north India. Trop. Doct. 2021, 51, 181-184. [CrossRef]

33. Janovsky, C.C.P.S.; Cesena, F.H.; Valente, V.A.T.; Conceição, R.D.D.O.; Santos, R.D.; Bittencourt, M.S. Association between Thyroid-Stimulating Hormone Levels and Non-Alcoholic Fatty Liver Disease Is Not Independent from Metabolic Syndrome Criteria. Eur. Thyroid. J. 2018, 7, 302-307. [CrossRef] [PubMed]

34. Borges-Canha, M.; Neves, J.S.; Mendonça, F.; Silva, M.M.; Costa, C.; Cabral, P.M.; Guerreiro, V.; Lourenço, R.; Meira, P.; Salazar, D.; et al. Thyroid Function and the Risk of Non-Alcoholic Fatty Liver Disease in Morbid Obesity. Front. Endocrinol. 2020, 11, 572128. [CrossRef] [PubMed]

35. Wang, C.; Niu, Q.; Lv, H.; Li, Q.; Ma, Y.; Tan, J.; Liu, C. Elevated TPOAb is a Strong Predictor of Autoimmune Development in Patients of Type 2 Diabetes Mellitus and Non-Alcoholic Fatty Liver Disease: A Case-Control Study. Diabetes Metab. Syndr. Obes. Targets Ther. 2020, 13, 4369-4378. [CrossRef]

36. Huang, B.; Yang, S.; Ye, S. Association between Thyroid Function and Nonalcoholic Fatty Liver Disease in Euthyroid Type 2 Diabetes Patients. J. Diabetes Res. 2020, 2020, 6538208. [CrossRef]

37. Guo, Z.; Li, M.; Han, B.; Qi, X. Association of non-alcoholic fatty liver disease with thyroid function: A systematic review and meta-analysis. Dig. Liver Dis. 2018, 50, 1153-1162. [CrossRef]

38. Mantovani, A.; Nascimbeni, F.; Lonardo, A.; Zoppini, G.; Bonora, E.; Mantzoros, C.S.; Targher, G. Association Between Primary Hypothyroidism and Nonalcoholic Fatty Liver Disease: A Systematic Review and Meta-Analysis. Thyroid 2018, 28, 1270-1284 [CrossRef] [PubMed]

39. He, W.; An, X.; Li, L.; Shao, X.; Li, Q.; Yao, Q.; Zhang, J.-A. Relationship between Hypothyroidism and Non-Alcoholic Fatty Liver Disease: A Systematic Review and Meta-analysis. Front. Endocrinol. 2017, 8, 335. [CrossRef]

40. Jaruvongvanich, V.; Sanguankeo, A.; Upala, S. Nonalcoholic Fatty Liver Disease Is Not Associated with Thyroid Hormone Levels and Hypothyroidism: A Systematic Review and Meta-Analysis. Eur. Thyroid. J. 2017, 6, 208-215. [CrossRef]

41. Martínez Escudé, A.; Pera, G.; Arteaga, I.; Expósito, C.; Rodríguez, L.; Torán, P.; Caballeria, L. Relationship between hypothyroidism and non-alcoholic fatty liver disease in the Spanish population. Med. Clín. 2020, 154, 1-6. [CrossRef]

42. Sinha, R.A.; You, S.-H.; Zhou, J.; Siddique, M.M.; Bay, B.-H.; Zhu, X.; Privalsky, M.L.; Cheng, S.-Y.; Stevens, R.D.; Summers, S.A.; et al. Thyroid hormone stimulates hepatic lipid catabolism via activation of autophagy. J. Clin. Investig. 2012, 122, 2428-2438. [CrossRef] [PubMed]

43. Fuchs, C.; Claudel, T.; Trauner, M. Role of metabolic lipases and lipolytic metabolites in the pathogenesis of NAFLD. Trends Endocrinol. Metab. 2014, 25, 576-585. [CrossRef]

44. Lonardo, A.; Mantovani, A.; Lugari, S.; Targher, G. NAFLD in Some Common Endocrine Diseases: Prevalence, Pathophysiology, and Principles of Diagnosis and Management. Int. J. Mol. Sci. 2019, 20, 2841. [CrossRef]

45. Singh, B.K.; Sinha, R.A.; Yen, P.M. Novel Transcriptional Mechanisms for Regulating Metabolism by Thyroid Hormone. Int. J. Mol. Sci. 2018, 19, 3284. [CrossRef]

46. Hu, D.-S.; Zhu, S.-H.; Liu, W.-Y.; Pan, X.-Y.; Zhu, P.-W.; Li, Y.-Y.; Zheng, I.K.; Ma, H.-L.; You, J.; Targher, G.; et al. PNPLA3 polymorphism influences the association between high-normal TSH level and NASH in euthyroid adults with biopsy-proven NAFLD. Diabetes Metab. 2020, 46, 496-503. [CrossRef]

47. Dullaart, R.P.; Berg, E.H.V.D.; Van Der Klauw, M.M.; Blokzijl, H. Low normal thyroid function attenuates serum alanine aminotransferase elevations in the context of metabolic syndrome and insulin resistance in white people. Clin. Biochem. 2014, 47, 1028-1032. [CrossRef] [PubMed] 
48. Gionfra, F.; De Vito, P.; Pallottini, V.; Lin, H.-Y.; Davis, P.J.; Pedersen, J.Z.; Incerpi, S. The Role of Thyroid Hormones in Hepatocyte Proliferation and Liver Cancer. Front. Endocrinol. 2019, 10, 532. [CrossRef]

49. Kim, D.; Yoo, E.R.; Li, A.; Fernandes, C.; Tighe, S.; Cholankeril, G.; Hameed, B.; Ahmed, A. Low-Normal Thyroid Function Is Associated With Advanced Fibrosis Among Adults in the United States. Clin. Gastroenterol. Hepatol. 2019, 17, $2379-2381$. [CrossRef]

50. Bano, A.; Chaker, L.; Plompen, E.P.C.; Hofman, A.; Dehghan, A.; Franco, O.H.; Janssen, H.L.A.; Murad, S.D.; Peeters, R.P. Thyroid Function and the Risk of Nonalcoholic Fatty Liver Disease: The Rotterdam Study. J. Clin. Endocrinol. Metab. 2016, 101, $3204-3211$. [CrossRef]

51. D'Ambrosio, R.; Campi, I.; Maggioni, M.; Perbellini, R.; Giammona, E.; Stucchi, R.; Borghi, M.; Degasperi, E.; De Silvestri, A.; Persani, L.; et al. The relationship between liver histology and thyroid function tests in patients with non-alcoholic fatty liver disease (NAFLD). PLoS ONE 2021, 16, e0249614. [CrossRef]

52. Martínez-Escudé, A.; Pera, G.; Rodríguez, L.; Arteaga, I.; Expósito-Martínez, C.; Torán-Monserrat, P.; Caballería, L. Risk of Liver Fibrosis According to TSH Levels in Euthyroid Subjects. J. Clin. Med. 2021, 10, 1350. [CrossRef]

53. Bano, A.; Chaker, L.; Muka, T.; Mattace-Raso, F.U.S.; Bally, L.; Franco, O.H.; Peeters, R.P.; Razvi, S. Thyroid Function and the Risk of Fibrosis of the Liver, Heart, and Lung in Humans: A Systematic Review and Meta-Analysis. Thyroid 2020, 30, 806-820. [CrossRef]

54. Liu, L.; Yu, Y.; Zhao, M.; Zheng, D.; Zhang, X.; Guan, Q.; Xu, C.; Gao, L.; Zhao, J.; Zhang, H. Benefits of Levothyroxine Replacement Therapy on Nonalcoholic Fatty Liver Disease in Subclinical Hypothyroidism Patients. Int. J. Endocrinol. 2017, 2017, 5753039. [CrossRef] [PubMed]

55. Bruinstroop, E.; Dalan, R.; Cao, Y.; Bee, Y.M.; Chandran, K.; Cho, L.W.; Soh, S.B.; Teo, E.K.; Toh, S.-A.; Leow, M.K.S.; et al. Low-Dose Levothyroxine Reduces Intrahepatic Lipid Content in Patients With Type 2 Diabetes Mellitus and NAFLD. J. Clin. Endocrinol. Metab. 2018, 103, 2698-2706. [CrossRef] [PubMed]

56. Ladenson, P.W.; Kristensen, J.D.; Ridgway, E.C.; Olsson, A.G.; Carlsson, B.; Klein, I.; Baxter, J.D.; Angelin, B. Use of the Thyroid Hormone Analogue Eprotirome in Statin-Treated Dyslipidemia. N. Engl. J. Med. 2010, 362, 906-916. [CrossRef]

57. Harrison, A.S.; Bashir, M.R.; Guy, C.D.; Zhou, R.; Moylan, C.A.; Frias, J.P.; Alkhouri, N.; Bansal, M.B.; Baum, S.; NeuschwanderTetri, A.B.; et al. Resmetirom (MGL-3196) for the treatment of non-alcoholic steatohepatitis: A multicentre, randomised, double-blind, placebo-controlled, phase 2 trial. Lancet 2019, 394, 2012-2024. [CrossRef] 